\title{
POLA KOMUNIKASI DALAM PEMBERIAN SANKSI ADAT TERHADAP PELAKU KAWIN LARI
}

\author{
Oleh: \\ YANTO \\ Program Studi Ilmu Komunikasi Fakultas Ilmu-Ilmu Sosial \\ Universitas Dehasen Bengkulu
}

\begin{abstract}
In order to achieve a common goal in a society, sometimes the exchange of messages can be biased, therefore it is important how the communication patterns in giving a support to the elopement, so that problems do not arise in the future. Therefore, the writer wants to see and know the communication patterns that take place in the granting of sanctions to the elopement in BatuEjung village. This type of research is qualitative research, data sources in this study were taken from primary data and secondary data, data collection techniques were carried out by interview observation and documentation. Analysis techniques by data reduction, data presentation, then drawing conclusions / verification. The results of studies of various types of communication patterns, ranging from primary communication patterns, secondary communication patterns, linear communication patterns and circular communication patterns, the most suitable and approaching in sanctioning elopement actors are primary communication patterns because they include which elements in the pattern This is divided into two symbols, verbal symbols and nonverbal symbols. In verbal or language symbols, it can be seen how dialogue patterns that occur between indigenous people and the host convey the problem directly, in a nonverbal pattern the process of communicating thoughts by the communicator to the communicant using a symbol, known as "tepunjung" both yellow arbor and white arbor, and payment of a fine in cash.
\end{abstract}

Keywords: communication patterns, customs, elopement

\section{PENDAHULUAN}

Setiap orang tidak akan bisa terlepas dari komunikasi, sebab dengan berkomunikasi orang akan mendapat kemudahan dalam hidupnya. Dalam hidup bermasyarakat seseorang akan memperoleh kemudahan dalam hidupnya karena memiliki banyak sahabat. Melalui komunikasi, juga kita dapat berusaha membina hubungan yang baik, sehingga menghindari dan mengatasi terjadinya konflik - konflik di antara kita, apakah dengan tetangga, teman kantor, atau dengan orang lain (Cangara, 2012).

Cangara (2012:3) mengungkapkan bahwa dalam melakukan komunikasi yang baik akan menghasilkan umpan yang baik pula. Komunikasi diperlukan untuk mengatur tata krama pergaulan antar manusia, sebab berkomunikasi dengan baik akan member pengaruh langsung pada 
struktur keseimbangan seseorang dalam bermasyarakat.

Dalam kehidupan masayarakat ada beberapa aturan yang akan diterapkan salah satuya adalah hokum adat, banyak hal yang diatur dalam hukum adat, salah satunya adalah hukum tentang perkawinan. Pernikahan merupakan ikatan lahir batin yang berdasarkan Ketuhanan Yang Maha Esa. Dalam Undang-Undang No 1 Tahun 1974 dijelaskan bahwa pernikahan adalah ikatan lahir batin antara seorang pria dan wanita sebagai suami istri dengan tujuan membentuk keluarga (rumah tangga) yang bahagia dan kekal berdasarkan ketuhanan yang maha esa.

Unsur pokok suatu perkawinan dalam syari'at agama Islam adalah laki-laki dan perempuan yang akan kawin, akad perkawinan itu sendiri, wali yang melangsungkan akad dengan si suami, dua orang saksi yang menyaksikan telah berlansungnya akad perkawinan dan mahar. Para ulama menetapkan akad, kedua mempelai, wali si perempuan dan saksi sebagai rukun dari perkawinan, yang bila tidak ada salah satu diantaranya perkawinan tersebut tidak sah. (Amir Syarifudin, 2003:81).

Bentuk ketidakhadiran wali atau waliadhal dalam hukum Islam, dalam hokum adat dinamakan dengan kawin lari. Dalam hokum adat di Indonesia kawin lari terbagi lagi kepada dua bentuk yaitu : (Soerjono Soekanto,1990:248)

1. Kawin Lari Bersama yaitu bila calon Istri-Suami melakukan lari bersama dengan tiada peminangan atau pertunangan secara formal, maka terjadi perkawinan lari bersama atau sama-sama melarikan diri. Perkawinan dengan cara lari bersama ini dilakukan untuk menghindarkan diri dari berbagai keharusan sebagai akibat perkawinan dengan cara pelamaran atau peminangan, atau juga untuk menghindarkan diri dari rintangan - rintangan dari pihak orang tua dan sanak saudara, yang terutama datangnya dari pihak orang tua dan sanak saudara pihak perempuan.

2. Perkawinan Bawa Lari adalah berupa lari dengan seorang perempuan yang sudah ditunangkan atau dikawinkan dengan orang lain atau membawa lari perempuan dengan paksaan.

Dalam adat desa Batu Ejung, bentuk kawin lari yang banyak dilakukan adalah kawin lari dalam bentuk pertama, yaitu kawin lari bersama yaitu dilakukan dengan cara seorang laki - laki dan perempuan melarikan bersama-sama untuk melansungkan pernikahan keluar daerah dengan tanpa izin dan sepengetahuan orang tua, keluarga dan adatdesa.

Dalam hukum adat di Indonesia tidak mengatur tentang sanksi kawin lari, begitu pun dengan hukum Islam juga tidak menetapkan sanksi terhadap pernikahan yang dilakukan dengan ketidakhadiran walinasab dan akan dinikah kan oleh wali hakim, tetapi berbeda halnya dengan adat yang berlaku di desa Batu Ejung, yang menerapkan sanksi adat bagi pelaku kawin lari.

Dalam aturan adat desa Batu Ejung, kawin lari yang dilakukan oleh masyarakat Batu Ejung merupakan pembangkangan dan perlawanan terhadap adat desa Batu Ejung, maka bagi siapa yang melakukannya akan dikenakan sanksi adat, sebagaimana yang tercantum dalam Peraturan Adat Desa Batu Ejung Nomor 01 tahun 2017 Pasal 4 yakni membayar denda dan berbagai ritual .

Demi tercapainya sebuah tujuan bersama dalam suatu masarakat kadang pertukaran pesan bisa menjadi bias, oleh karena itu ada beberapa pola yang bisa terbentuk dalam komunikasi terutama dalam komunikasi adat, terlebih dalam pemberian sanksi terhadap pelaku kawin lari, agar tidak muncul permasalahan di kemudian hari, mengingat pemberian sanksi adalah suatu 
hukuman yang diterima oleh pelaku, agar menyenangkan semua pihak maka perlu pola komunikasi yang baik dalam pemberian sanksi tersebut.

Pola Komunikasi adalah proses yang dirancang untuk mewakili kenyataan keterpautannya unsur - unsur yang dicakup beserta keberlangsunganya, guna memudahkan pemikiran secara sistematik dan logis (Effendy,1989). Pola komunikasi merupakan bagian dari proses komunikasi. proses komunikasi akan dapat ditemukan pola yang cocok dan mudah digunakan dalam berkomunikasi.

Berdasarkan latar belakang diatas, peneliti ingin melihat lebih lanjut dalam sebuah penelitian mengenai pola komunikasi yang berlangsung dalam pemberian Sanksi Adat terhadap pelaku Kawin Lari di Desa Batu Ejung Kecamatan Teramang Jaya Kabupaten Muko-Muko Provinsi Bengkulu.

\section{METODE PENELITIAN}

Penelitian ini menggunakan jenis pendekatan penelitian kualitatif. Penelitian kualitatif ditujukan untuk mendeskripsikan dan menganalisis fenomena, peristiwa, aktivitas sosial, kepercayaan, persepsi, dan pemikiran orang secara individual ataupun kelompok.

Bungin (2003:302) mengatakan, pendekatan kualitatif memusatkan perhatian pada prinsip- prinsip umum yang mendasari perwujudan sebuah makna dari gejala-gejala sosial di masyarakat. Objek analisisnya adalah makna dari gejala-gejala sosial dan budaya dengan mempelajari pola komunikasi yang dibentuk dalam pemberian sanksi kepada pelaku kawin lari yang ada di desa Batu Ejung.

\section{Sumber Data}

\section{A. Sumber Data Primer}

Data primer yaitu data yang diperoleh dari respon dan langsung dari orang- orang atau sumber pertama. Data primer dari penelitian ini adalah data yang diperoleh dari ketua adat desa Batu Ejung, kepala kaum desa Batu Ejung, peraturan adat desa Batu Ejung dan pelaku.

B. Sumber Data Sekunder

Data sekunder adalah data yang terlebih dahulu ditelusuri dan dilaporkan oleh orang lain diluar peneliti. Data sekunder meliputi dokumen-dokumen, arsip-arsip, catatan-catatan, gambar-gambar terkait dengan penelitian ini.

\section{Teknik PengumpulanData}

Teknik pengumpulan data merupakan langkah yang paling strategis dalam penelitian, karena tujuan utama dari penelitian adalah mendapatkan data. Dalam usaha pengumpulan data serta keterangan yang diperlukan dalam penelitian ini adalah penulis menggunakan metode pengumpulan data sebagai berikut:

\section{Obeservasi}

Nasution dalam Sugiono (2005:64) menyatakan bahwa observasi adalah dasar semua ilmu pengetahuan. Yaitu fakta mengenai dunia kenyataan yang diperoleh melalui observasi. Sebagai pengamatan dan pencatatan secara sistematis terhadap gejala yang tampak pada objek penelitian. Dalam melakukan observasi ini peneliti menggunakan akan menyatakan terus terang kepada sumber data, bahwa sedang melakukan penelitian. Jadi mereka yang diteliti mengetahui sejak awal sampai akhir tentang aktivitas peneliti (Sugiono, 2005:66). Metode observasi ini penulis gunakan untuk mengadakan observasi pendahuluan, pengamatan langsung mengenai kegiatan yang berkaitan dengan pola komunikasi pemberian sanksi adat pada pelaku kawin lari di desaBatu Ejung. 
2. Wawancara

Menurut Bungin (2003:108) wawancaraa dalah proses memperoleh keterangan untuk tujuan penelitian dengan tanya jawab sambil tatap muka antara pewawancara dengan responden atau orang yang diwawancarai dengan atau tanpa mengunakan pedoman. Metode pengumpulan data yang dilakukan melalui wawancara untuk mendapatkan informasi secara langsung dengan mengungkapkan pertanyaan pada para responden. Untuk mendapatkan informasi yang relative lebih objektif, maka wawancara di sini dilakukan terhadap satu orang responden, yang termasuk responden yang sekiranya dapat membantu peneliti untuk memberikan informasi dan untuk melengkapi data yang diperoleh melalui observasi. Data yang diperoleh dengan interview ini mengenai informasi dan data tentang hal-hal yang bersifat objektif. Dalam melakukan wawancara peneliti manggunakan metode wawancara semi terstruktur, dimana dalam pelaksanaannya lebih bebas. Tujuan dari wawancara ini adalah untuk menemukan permasalahan lebih terbuka, dimana pihak yang diajak wawancara diminta pendapat, dan ideidenya.

3. Dokumentasi

Menurut Guba dan Lincol dalam Moleong (2000:161) dokumentasi adalah setiap bahan tertulis atau film dari record yang tidak dipersiapkan karena adanya permintaan dari seorang penyelidik. Metode documenter merupakan pengumpulan data yang diperoleh dari berbagai catatan atau arsip penting. Metode ini digunakan untuk memperoleh data tentang segalapenjelasan, serta menunjang validitas dan efektifitas dalam pengambilan data, yakni struktur sejarah, sumber daya manusia, dan sebagainya.

\section{Teknik Analisis Data}

Langkah yang diambil dalam teknik analisis data dalam penelitian ini ialah menggunakan analisis data kualitatif oleh model interaktif Miles \& Huberman (1992:20). Dimana analisis, yang dilakukan ialah pengumpulan data terdiri atas tiga alur kegiatan yang terjadi secara bersamaan yaitu: reduksi data, penyajian data, penarikan kesimpulan/verifikasi. Pada reduksi data yang diartikan sebagai proses pemilihan, pemusatan perhatian pada penyederhanaan, pengabstrakan, dan transformasi data "kasar" yang muncul dari catatan-catatan tertulis di lapangan hingga berlanjut terus sesudah penelitian lapangan, sampai laporan akhir lengkap tersusun.

Sedangkan pada penyajian data yang diartikan sebagai sekumpulan informasi tersusun yang memberikan kemungkinan adanya penarikan kesimpulan dan pengambilan tindakan, selain itu juga dengan melihat penyajian-penyajian penulis akan dapat memahami apa yang sedang terjadi dan apa yang harus dilakukan. Kegiatan analisis ketiga yang penting adalah menarik kesimpulan dan verifikasi. Kesimpulan-kesimpulan "final" mungkin tidak muncul sampai pengumpulan data terakhir, tergantung pada besarnya kumpulan-kumpulan catatan lapangan, observasi, pengkodeannya, penyimpangan, dan kecakapan penelitian.

\section{HASIL PENELITIAN}

Pola komunikasi adalah proses yang dirancang untuk mewakili kenyataan keterpautan unsur-unsur yang dicakup beserta keberlangsungan, guna memudahkan pemikiran secara sistematik dan logis. Begitu juga halnya penegekan hokum adat bertujuan untuk menentramkan dan merubah perilaku masyarakat yang adadisekitar adat. 
Dan pola penyampaian pesan harus juga dilakukan dengan baik. Dalam komunikasi dikenal beberapa pola, dalam pemberian sanksi adat kepada pelaku kawin lari lebih mendekati pola primer yang mana lambanglambang yang digunakan baik itu verbal maupun non verbal. Penegakan hukum adat sebuah kewajiban ditegakkan pola komunikasi dalam pemberian sanksi adat terhadap pelaku kawin lari.

\section{Pelaksanaan Sanksi Adat Kawin Lari Di Desa Batu Ejung}

Dalam aturan adat desa Batu Ejung, kawin lari tercantum dalam Peraturan Adat Desa Batu Ejung Nomor 01 tahun 2017 Pasal 4 berupa : "Membayar denda Adat sebesar Rp 1.000.000,-, Satu buah Punjuang Kuning dan satu buah Punjuang Putih serta bermaaf-maafan kepada majelis yang hadir". Pada ayat berikutnya, jika sanksi adat tersebut tidak dilaksanakan maka "keluarga yang bersangkutan belum bisa dilayani pekerjaan baik maupun pekerjaan buruk di rumahnya oleh orang adat. Dari aturan yang ditegakkan dan pemberian sanksi kepada pelaku kawin lari ada beberapa langkah awal yang harus dilalui diantaranya:

1. Orang tua menyampaikan kepada kepala kaum, untuk dilakukan penyelesaian

2. Kepala kaum menyampaikan perihal tersebut kepada ketua adat bahwa anak kaumnya telah melakukan kawin lari dan berdasarkan laporan orang tuanya

3. Ketuaadat menjadwalkan pelaksanaan penyelesaian masalah

4. Kepala kaum mengundang pegawai adat yang terdiri dari: ketua adat, kepalakepala kaum yang lain dan kepaladusun. Dan pegawa isyara' yang terdiri dari: Imam Kadi, Khatib dan Bilal.

Setelah melakukan kawin lari, orang tua menyampaikan perihal kawin lari yang telah dilakukan oleh anaknya kepada kepala kepala kaumnya dan bermaksud untuk mencari jalan penyelesaiannya secara adat desa Batu Ejung. Setelah mendapat laporan dari anak kaumnya, kepala kaum menyampaikan perihal tersebut kepada ketua adat bahwa anak kaumnya telah melakukan kawin lari dan berdasarkan laporan orang tuanya bermaksud untuk mencari penyelesaiannya secara adat yaitu dengan melaksanakan sanksi adat sebagaimana ketentuan adat desa Batu Ejung.

Setelah dikomunikasikan dengan ketua adat tentang jadwal pelaksanaan pembayaran sanksi adat, maka kepala kaum memerintahkan kepada orang tua yang bersangkutan untuk menyiapkan seluruh perlengkapan berupa punjuang kuniang, punjuang putiah dan uang sejumlah Rp.1.000.000,- (satu juta rupiah). Selanjutnya, kepala kaum mengundang pegawai adat yang terdiri dari ketua adat, kepala-kepala kaum yang lain dan kepala dusun. Dan pegawai syara' yang terdiri dari : Imam Kadi, Khatib dan Bilal.

\section{Tahapan Pelaksanaan Pembayaran Sanksi Adat Kawin Lari}

Adapun tahapan dalam pelaksanaan pembayaran sanksi adat kawin lari adalah sebagai berikut :

1. Dimulai oleh kepala kaum yang bersangkutan dengan menyampaikan maksud undangan dan kesalahan yang telah dilakukan oleh anak kaumnya dan bermaksud untuk melaksanakan sanksi adat sebagaimana peraturan adat desa Batu Ejung.

2. Dijawab oleh kepala dusun dengan untuk dilakukan pembayaran sanksi adat.

3. Diperintahkan oleh kepala kaum kepada kedua pasangan untuk menyampaikan ucapan mohon maaf karena telah menyalahi aturan adat desa Batu Ejung dengan menyalami majlis yang hadir satu persatu secara bergiliran. 
4. Kemudian dilanjutkan dengan doa pernikahan yang dipimpin oleh saih (pembantu pegawai syara').

5. Dilanjutkan dengan makan bersama, Kemudian dihidangkanlah punjuang putih dihadapan Imam Kadi dan punjuang kuniang dihadapan Ketua Adat, serta makan-makanan lainnya yang sudah disiapkan oleh tuan rumah.

6. Penyampaian nasehat kepada pengantin oleh ketua adat tentang adat istiadat serta perlunya menaati adat istiadat dalam desa. Kemudian nasehat disampaikan imam kadi tentang nasehat keagamaan.

7. Pembagian uang denda dengan pembagian sebagai berikut :

a. Untuk kepala kaum yang bersangkutan Rp.100.000,-

b. Untuk ketua adat Rp100.000,-

c. Untuk majelis yang hadir Rp.800.000,-

8. Diakhiri dengan penyampaian kata-kata pamitan pulang oleh kepala dusun serta dijawab oleh kepala kaum yang bersangkutan.

\section{Pola Komunikasi Primer}

Pola komunikasi primer merupakan suatu proses penyampaian pikiran oleh komunikator kepada komunikan dengan menggunakan suatu lambang sebagai media atau saluran. Dalam pola ini terbagi menjadi dua lambing yaitu lambang verbal dan lambang non verbal. (Onong Uchjana Efendy, 2003 :33).

1. Lambang Verbal

Dalam proses komunikasi bahasa sebagai lambang verbal paling banyak dan paling sering digunakan, oleh karena hanya bahasa yang mampu mengungkapkan pikiran komunikator mengenai hal atau peristiwa, baik yang konkret maupun yang abstrak, yang terjadi masa kini, masa lalu dan masa yang akan datang.

2. Lambang Non Verbal

Lambang non verbal adalah lambang yang dipergunakan dalam komunikasi, yang bukan bahasa, misalnya kias, isyarat dengan anggota tubuh, antara lain kepala, mata, bibir, tangan, dan jari.

Pola komunikasi ini dinilai sebagai model klasik, karena model ini merupakan model pemula yang dikembangkan Aristoteles, kemudian Lasswell hingga Shannon dan Weaver (HafiedCangara, 1998:45). Dari hasil temuan di lapangan dapat diketahui bahwa pola komunikasi yang dilakuan oleh adat dalam pemberian sanksi yaitu pola komunikasi primer atau dikenal juga dengan model klasik. Yang terdiri atas tiga unsur, yakni: komunikator, pesan, dan komunikan. Yang menjadi komunikator dalam hal ini adalah perangkat adat dalam hal ini ketua adat dan kepala kaum, adapun pesan yang disampaikan berupa hukuman-hukuman yang berlaku sesuai dengan peraturan yang berlaku, sedangkan yang menjadi komunikan adalah bukan saja kedua mempelai akan tetapi keluarga besar kedua mempelai, karena hukumannya juga berlaku untuk sekeluarga.

Dalam pola komunikasi primer dikenal juga dengan proses penyampaian pikiran oleh komunikator kepada komunikan dengan menggunakan suatu symbol dalam pemberian sangsi adat dikenal dengan bahasa"tepunjung" baik punjung kuning maupun punjung putih serta bermaaf-maafan kepada majelis yang melambangkan sebuah simbol penghargaan kepada nenek moyang untuk menjaga jangan ada perbuatan yang mengganggu keseimbangan masyarakat yang dikaitkan dengan keagamaan dan mistis.

Selanjutnya dalam komunikasi primer lambang nonverbal adalah lambang yang dipergunakan dalam komunikasi, yang bukan bahasa yaitu sanksi adat berupa, membayar sejumlah uang denda adat merupakan sebuah tanggungjawab yang harus dipinggul oleh pasangan yang melakukan kawin lari, dengan adanya denda seperti ini diharapkan ada efek jera yang 
diberikan kepda para pelaku yang berniat melakukan kawin lari.

Bahasa sebagai lambang verbal yaitu paling banyak dan paling sering digunakan, karena bahasa mampu mengungkapkan pikiran komunikator dalam hal ini jelas terlihat bagaimana dialog yang terjadi antara orang adat dan tuan rumah yang bersifat dialogis., dimana orang-orang adat menyampaikan pandangan yang telah dilakukan oleh pelaku kawin lari, dan efek yang ditimbulkan, bahwa apabila hukuman ini tidak dilakukan, atau tidak dipenuhi, makabukan hanya pelaku kawin lari yang menerima hukuman, melainkan keluarga kedua belah pihak, tidak akan dilayani dan tidak diikutsertakan dalam kegiatan baik maupun kegiatan buruk didalam masyarakat desa. Dan keluarga yang bersangkutan belum bisa dilayani pekerjaan baik maupun buruk di rumahnya oleh orang adat desa Batu Ejung.

\section{PENUTUP}

\section{Kesimpulan}

Komunikasi akan dapat ditemukan pola yang cocok dan mudah digunakan dalam berkomunikasi, dalam hal pemberian sanksi adat terhadap pelaku kawin lari penulis dapat menarik kesimpulan bahwa pola yang tepat digunakan adalah pola komunikasi primer yang mana dalam pola ini terbagi menjadi dua lambang yaitu lambang verbal dan lambang non verbal sehingga memadukan keduanya menjadi proses komunikasi dengan pola ini akan lebih efektif.

Dalam pola non verbal proses penyampaian pikiran oleh komunikator kepada komunikan dengan menggunakan suatu simbol, dalam hal ini pemberian sanksi adat dikenal dengan bahasa "tepunjung" baik punjung kuning maupun punjung putih. dan membayar sejumlah uang denda adat. Dalam lambang verbal atau bahasa yaitu paling banyak dan paling sering digunakan, terlihat bagaimana pola komunikasi yang bersifat dialog yang terjadi antara orang adat dan tuan rumah pada saat pelaksanaan penyelesaian pemberian sanksi kepada pelaku kawin lari dan orang tua.

\section{Saran}

Hendaknya dalam pemberian sanksi terhadap pelaku kawin lari, juga mengundang perangkat pemerintahan karena dalam ketatanan pemerintah, kepala desa menjadi orang nomor satu di desa.

\section{DAFTAR PUSTAKA}

Arni, Muhammad. 2004. Komunikasi Organisasi. Jakarta, Bumi Aksara

Bungin, Burhan. 2003. Metode Penelitian Kualitatif. Jakarta, PT Raja Grafindo Persada.

Cangara, Hafied. 2012 Pengantar Ilmu Komunikasi. Jakarta, PT Raja Grafindo Persada.

Efendy, Onong Uchjana. 2003. Ilmu, Teori dan Filsafat Komunikasi. Bandung, PT. Citra Aditya Bakti

Effendy, Onong Uchjana. 1993. Dinamika Komunikasi. Bandung, PT. Remaja Rosdakarya

Hadikusuma, Hilman. 1977. Hukum Perkawinan Indonesia. Bandung, Alumni,

Kamus Besar Bahasa Indonesia. 1996. Jakarta, Balai Pustaka,

Marhaeni, Fajar. 2009. Ilmu Komunikasi Teori\&Praktik. Yogyakarta, Graha Ilmu,.

Nico, Ngani. 2012. Perkembangan Hukum Adat di Indonesia. Yogyakarta, Pustaka Yustisia

Setiady, Tolib. 2009. Intisari Hukum Adat Indonesia Dalam Kajian Kepustakaan. Bandung, Alfabeta

Sobur,Alex, 2006. Ensiklopedia Komunikasi Jakarta, Simbiosa Rekatama 
Soebekti. 1997 Asas-Asas dan Susunan Hukum Adat. Jakarta, PT. Pradnya

Soerjono, Soekanto. 1990. Hukum Adat Di Indonesia. Jakarta, Rajawali

Sukmadinata, Nana Syaodih. 2012 Metode Penelitian Pendidikan. Bandung, Remaja Rosdakarya

Suharsimi, Arikunto. 2006. Prosedur Penelitian. Bandung, Rosda Karya
Susanto, Eko Harry. 2010. Komunikasi Manusia Esensi dan Aplikasi dalam Dinamika Sosial Ekonomi Politik, Jakarta, Mitra Wacana Media

Syahuri, Taufiqurrahman. 2013. Legislasi Hukum Perkawinan Di Indonesia. Jakarta, Kencana Paramita

Syarifudin, Amir. 2003. Garis-Garis Besar Fiqh. Jakarta, Prenada Media

Wiryanto. 2004 Pengantar Ilmu Komunikasi. Jakarta, Gramedia 